\title{
Effects of Different Potato Cropping System Approaches and Water Management on Soilborne Diseases and Soil Microbial Communities
}

\author{
Robert P. Larkin, C. Wayne Honeycutt, Timothy S. Griffin, O. Modesto Olanya, John M. Halloran, and Zhongqi He
}

United States Department of Agriculture-Agricultural Research Service, New England Plant, Soil, and Water Laboratory, Orono, ME 04469. Current address of Tim Griffin: Tufts University, Friedman School of Nutrition Science and Policy, Boston, MA 02111.

Accepted for publication 2 September 2010.

\section{ABSTRACT}

Larkin, R. P., Honeycutt, C. W., Griffin, T. S., Olanya, O. M., Halloran, J. M., and He, Z. 2011. Effects of different potato cropping system approaches and water management on soilborne diseases and soil microbial communities. Phytopathology 101:58-67.

Four different potato cropping systems, designed to address specific management goals of soil conservation, soil improvement, disease suppression, and a status quo standard rotation control, were evaluated for their effects on soilborne diseases of potato and soil microbial community characteristics. The status quo system (SQ) consisted of barley underseeded with red clover followed by potato (2-year). The soil-conserving system (SC) featured an additional year of forage grass and reduced tillage (3-year, barley/timothy-timothy-potato). The soil-improving system (SI) added yearly compost amendments to the SC rotation, and the disease-suppressive system (DS) featured diverse crops with known disease-suppressive capability (3-year, mustard/rapeseed-sudangrass/ryepotato). Each system was also compared with a continuous potato control (PP) and evaluated under both irrigated and nonirrigated conditions. Data collected over three potato seasons following full rotation cycles demonstrated that all rotations reduced stem canker (10 to 50\%) relative to PP. The SQ, SC, and DS systems reduced black scurf (18 to 58\%) relative to PP; SI reduced scurf under nonirrigated but not irrigated conditions; and scurf was lower in DS than all other systems. The SQ, SC, and DS systems also reduced common scab (15 to 45\%), and scab was lower in DS than all other systems. Irrigation increased black scurf and common scab but also resulted in higher yields for most rotations. SI produced the highest yields under nonirrigated conditions, and DS produced high yields and low disease under both irrigation regimes. Each cropping system resulted in distinctive changes in soil microbial community characteristics as represented by microbial populations, substrate utilization, and fatty acid methyl-ester (FAME) profiles. SI tended to increase soil moisture, microbial populations, and activity, as well result in higher proportions of monounsaturated FAMEs and the FAME biomarker for mycorrhizae $(16: 1 \omega 6 \mathrm{c})$ relative to most other rotations. DS resulted in moderate microbial populations and activity but higher substrate richness and diversity in substrate utilization profiles. DS also resulted in relatively higher proportions of FAME biomarkers for fungi $(18: 2 \omega 6 \mathrm{c})$, actinomycetes, and gram-positive bacteria than most other systems, whereas PP resulted in the lowest microbial populations and activity; substrate richness and diversity; proportions of monounsaturated and polyunsaturated FAME classes; and fungal, mycorrhizae, and actinomycete FAME biomarkers of all cropping systems. Overall, soil water, soil quality, and soilborne diseases were all important factors affecting productivity, and cropping systems addressing these constraints improved production. Cropping system approaches will need to balance these factors to achieve sustainable production and disease management.
Potato (Solanum tuberosum L.) production systems in the northeast United States are characterized by short (2-year) rotations, extensive tillage, minimal crop residue return, and minimal crop diversity. The overall productivity of these systems has remained stable for several decades, despite increasing inputs of pesticides, nutrients, and water (24). Potato production faces numerous constraints to productivity and profitability, including the lack of profitable rotation crops, high potential for disease problems, high fertilizer and pesticide requirements, degrading soil quality, and variable rainfall during the growing season. The long-term sustainability of potato production will depend on balancing the physiological production requirements of the crop with overcoming these additional constraints. Improved cropping systems that address the most important constraints should

Corresponding author: R. P. Larkin; E-mail address: Bob.Larkin@ars.usda.gov

Mention of trade names or commercial products in this article is solely for the purpose of providing specific information and does not imply recommendation or endorsement by the United States Department of Agriculture.

doi:10.1094/PHYTO-04-10-0100

This article is in the public domain and not copyrightable. It may be freely reprinted with customary crediting of the source. The American Phytopathological Society, 2011. improve production. Unfortunately, little is known regarding the specific interactions and relative contributions of these various constraints and factors to overall productivity.

Numerous soilborne diseases are persistent, recurrent problems in potato production, resulting in reduced plant growth and vigor, lower tuber quality, and reduced yield. Soilborne potato diseases of most concern in the northeast United States and other potatogrowing regions include Rhizoctonia canker and black scurf, caused by Rhizoctonia solani; common scab, caused by Streptomyces scabiei; powdery scab, caused by Spongospora subterranea f. sp. subterranea; white mold, caused by Sclerotinia sclerotiorum; silver scurf, caused by Helminthosporium solani; pink rot, caused by Phytophthora erythroseptica; and Verticillium wilt, caused by Verticillium dahliae. Most of these diseases are difficult to control, and there are few effective control measures readily available.

Current 2-year rotations primarily use a low-maintenance grain forage crop (such as barley or oat) as the rotation crop. Although these 2-year rotations have been shown to reduce soilborne disease levels compared with continuous potato $(28,65)$, longer rotation lengths of 3 or 4 years between potato crops are known to be much more effective in controlling soilborne diseases $(10,26$, 57,61). The use of crops with known disease-suppressive capabilities, such as Brassica spp. and sudangrass crops, and fall cover crops may provide additional resources for reducing diseases 
through improved cropping systems, as shown by our previous research (35-37). Such disease-suppressive cropping systems may suppress disease through a combination of biofumigation, manipulation of soil microbial communities, and other mechanisms. Through conserving or replenishing soil resources such as organic matter, effective cropping systems can alter soil chemical, physical, and biological properties $(2,29,30,42,43,55)$ that improve soil water management and reduce erosion $(2,22)$. Even larger or more rapid changes in soil fertility, structure, and microbial communities can be observed by adding green manures or other organic amendments, such as compost, which provide much greater biomass and organic matter than is achieved through crop rotation alone $(1,12,22,40,41,66,69)$.

Thus, specific management issues that can be directly addressed with cropping systems include soil conservation, soil improvement, and disease suppression. But which of these aspects will have the greatest impact? How can these goals be best achieved? And how will each of these approaches affect soilborne diseases and soil microbial communities, which may be important for future sustainability? Most previous research has focused primarily on effects of specific rotations or practices, and not on integrated cropping systems incorporating multiple aspects or approaches to improving productivity. Effects and interactions of these cropping system approaches on crop health and productivity need to be assessed.

In this research, cropping systems with specific management approaches for improving crop production were designed as an attempt to better understand how these various factors and interactions may be involved in constraining productivity, with specific focus on effects on soilborne disease and soil microbiology. This research was conducted as part of a larger project designed to identify and establish the relative contribution of factors that limit cropping system sustainability in the northeast United States. Beginning in 2004, in large-scale field trials in Maine, 3-year cropping systems designed to address management issues of soil conservation, soil improvement, and disease suppression were established and their subsequent effects on crop production were determined and compared with standards representing a typical potato cropping system and a nonrotation control under both irrigated and nonirrigated conditions. In this component of the overall research project, these cropping systems were evaluated for their effects and interactions on soilborne diseases and soil microbial community characteristics. Data were collected in the potato cropping year of each system following the complete rotation cycle in each of three growing seasons. Cumulative results from these three field seasons are presented. Subsequent reports will provide results from our interdisciplinary evaluation of these cropping systems on soil physical and chemical properties, plant nutrition, plant growth, tuber yield, economic viability, and other properties.

\section{MATERIALS AND METHODS}

Cropping systems. Cropping systems consisted of five different systems designed to address specific management goals of soil conservation, soil improvement, and disease suppression, as well as a system representing a typical standard rotation currently used in the northeast United States and a nonrotation control of continuous potato (Solanum tuberosum L.). An overview of the cropping systems and their features is provided in Table 1. The standard or "status quo" rotation (SQ) consisted of a 2-year rotation of barley (Hordeum vulgare L.) underseeded with red clover (Trifolium pretense L.) as a cover crop, followed by potato the following year. This system includes regular spring and fall tillage each year. The soil-conserving system (SC) consisted of a 3 -year rotation of barley underseeded with the forage grass timothy (Phleum pratense L); the timothy would overwinter and be allowed to continue undisturbed for a full year (second year), then be followed by potato in the third year. In this system, tillage would also be much reduced, with no tillage except immediately prior to planting potato and as needed for normal maintenance and harvest of the potato crop. The barley and timothy years would have no tillage, thus substantially improving soil conservation. In addition, straw mulch was applied after potato harvest to further conserve soil resources. The soil-improving system (SI) consisted of the same basic rotation as SC (3-year, barley/ timothy-timothy-potato, limited tillage, straw mulch) but with yearly additions of compost, to provide $\mathrm{C}$ and organic matter to improve soil quality. The disease-suppressive system (DS) was designed to make use of multiple strategies for suppressing soilborne diseases, including the use of disease-suppressive rotation crops, a longer rotation period, crop diversity, green manures, and fall cover crops. The DS system consisted of a 3-year rotation with the disease-suppressive Brassica 'Caliente 119' mustard blend (blend of oriental and white mustard seed, Brassica juncea L. and Sinapis alba L.) grown as a green manure, followed by a fall cover crop of rapeseed (B. napus L. 'Dwarf Essex') in the first year. In the second year, a disease-suppressive sorghum-sudangrass hybrid (Sorghum bicolor $\times$ S. bicolor var. sudanense L.) was grown as a green manure, followed by a fall cover crop of winter rye (Secale cereale L.), with potato in the third year. Continuous potato (PP) was the nonrotation control consisting of a potato crop planted in the same plots each year.

Field set-up and management. Long-term research plots were established in 2004 at the United States Department of Agriculture-Agricultural Research Service New England Plant, Soil and Water Laboratory Field Experimental Site in Presque Isle, $\mathrm{ME}$ as a split-block design with five replicate blocks, with irrigation and cropping system as the main and split factors, respectively. Soil type was a Caribou sandy loam (fine-loamy, isotic, frigid Typic Haplorthods). Each rotation entry point (representing each possible rotation crop for all years) was included in each block, so that each full rotation was represented each year (SQ, two entry points; SC, SI, and DS, three entry points; and PP, one entry point), resulting in 12 treatment plots (6 by $15 \mathrm{~m}$ each) per block for each of the irrigated and nonirrigated components. For the SQ system, plots were chisel plowed in the spring prior to barley planting and in the fall prior to the following year's potato planting. In the SC and SI systems, more soil-conserving practices were followed that included no tillage during non-potato years and spring tillage prior to potato. Seeding rates for barley, clover, and timothy were 112, 16.8, and $11.2 \mathrm{~kg} / \mathrm{ha}$, respectively. In addition, straw mulch was added at the rate of $2 \mathrm{Mg} /$ ha to the SC and SI systems shortly after potato

TABLE 1. Names, descriptions, and features of the cropping systems used to address specific management goals

\begin{tabular}{|c|c|c|c|c|}
\hline \multirow[b]{2}{*}{ Name } & \multicolumn{4}{|c|}{ Cropping system parameters } \\
\hline & Abbreviation & Length & Rotation description & Features \\
\hline Status quo & SQ & 2-year & Barley/clover-potato & Typical rotation (industry standard) \\
\hline Soil-conserving & $\mathrm{SC}$ & 3-year & Barley/timothy-timothy-potato & Additional year of forage, limited tillage, straw mulch after potato \\
\hline Soil-improving & SI & 3-year & Barley/timothy-timothy-potato & SC plus yearly compost amendments \\
\hline Disease-suppressive & DS & 3-year & $\begin{array}{l}\text { Mustard GM/rapeseed cover-sudangrass } \\
\text { GM/rye cover-potato }\end{array}$ & $\begin{array}{l}\text { Biofumigation crops, green manures, cover crops, and increased } \\
\text { crop diversity }\end{array}$ \\
\hline Continuous potato & PP & 1-year & Potato-potato & Nonrotation control \\
\hline
\end{tabular}


harvest. Yearly spring applications of composted dairy manure at $45 \mathrm{Mg} / \mathrm{ha}$ were made in the SI system. In the DS system, mustard and sudangrass green manures (seeding rates of 11.2 and $33.6 \mathrm{~kg} / \mathrm{ha}$, respectively) were grown for $\approx 2$ months, then flail mowed at peak biomass and incorporated into the soil with a rototiller. Fall cover crops were planted 2 weeks after incorporation of green manures.

As previously mentioned, all cropping systems were evaluated under both irrigated and rainfed management. Irrigation $(1.3 \mathrm{~cm})$ was applied with a lateral, overhead sprinkler system when tensiometer readings at the 10 - to $15-\mathrm{cm}$ depth exceeded $50 \mathrm{KPa}$.

In addition to the primary tillage for potato performed with a chisel plow in the fall (SQ and PP) or spring (SC, SI, and DS), secondary tillage of one to two diskings was also performed prior to planting. Cut seed pieces of potato cv. Russet Burbank were planted by hand in each plot (four rows, 0.9-m centers, with a $35-\mathrm{cm}$ spacing between plants). Potato plots were fertilized with the equivalent of $\mathrm{N}$ at $224 \mathrm{~kg} \mathrm{ha}^{-1}$ and $\mathrm{P}_{2} \mathrm{O}_{5}$ and $\mathrm{K}_{2} \mathrm{O}$ at $249 \mathrm{~kg} \mathrm{ha}^{-1}$. All potato plots were also sprayed with a preemergence herbicide (metribuzin at the rate of $1.0 \mathrm{~kg}$ a.i./ha) within 2 weeks after planting. In-season cultivation included one or two shallow passes with a cultivator and one pass with a hiller. Potato plots were also sprayed regularly throughout the growing season with alternating applications of mancozeb and chlorothalonil at recommended rates for the control of late blight. Potato crop assessments were begun in 2006, following the full 3-year rotation cycle of rotations begun in 2004, and continued in the subsequent years of 2007 and 2008. All other crops were managed using recommended production practices, including fertilizer rates, pesticide applications, and weed control measures for that particular crop.

Disease and yield assessments. In potato plots, plants were monitored in the field for signs and symptoms of soilborne diseases, including Rhizoctonia stem and stolon canker, white mold, and Verticillium wilt. In August of each year, two potato hills in each of two rows per plot, each containing multiple potato stems per plant, were destructively sampled (hand dug) to more accurately assess stem and stolon canker incidence and severity. Severity was determined on each stem or stolon using a 0 to 5 rating scale with $0=$ no symptoms; $1=$ discoloration, slight lesion; 2 = substantial lesion and necrosis covering $<50 \%$ of stem or stolon diameter; $3=$ lesion covering $>50 \%$ stem or stolon diameter; $4=$ large lesion girdling stem $(100 \%)$; and $5=$ stem (or stolon) girdled, plant (or stolon) dead. In October, potato tubers were harvested from the full length of the center two rows from each plot. Tubers were washed and graded. Yield was evaluated as the total weight of tubers per hectare, and marketable weight as the total weight of tubers greater than $114 \mathrm{~g}$ each. A subset of the harvested tubers, consisting of at least 30 tubers per plot of marketable weight, was rated for incidence and severity of soilborne diseases of tubers, including black scurf, common scab, powdery scab, and silver scurf. Disease severity for all tuber diseases was determined as the approximate percent surface coverage of the visible symptoms on each tuber.

Soil microbial community characteristics. Soil sampling. Soil samples were collected from all plots each spring for soil moisture and microbial analyses. Five soil cores $(7.5$ by $15 \mathrm{~cm})$ collected from throughout each plot were combined into one composite sample per plot, sieved through a 2-mm screen, and used for all subsequent analyses. Samples were stored in plastic bags at $10^{\circ} \mathrm{C}$ and processed within 1 to 4 weeks after sampling. For most assays, three subsamples were processed from each composite plot sample.

Soil microbial populations. General populations of culturable soil microorganisms were determined by soil dilution plating on agar media. For each of three subsamples from each composite soil sample, $10 \mathrm{~g}$ of soil was weighed and added to $90-\mathrm{ml}$ sterile $0.2 \%$ water agar, vigorously stirred for $5 \mathrm{~min}$, and serially diluted and plated on $0.1 \%$ tryptic soy agar (TSA) for total bacterial counts, and potato dextrose agar (PDA) with $50 \mathrm{mg}$ of chlortetracycline and tergitol at $1 \mathrm{ml}$ liter $^{-1}$ added for total fungal counts (38). Bacterial plates were incubated at $28^{\circ} \mathrm{C}$ for 3 days, and fungal plates at $25^{\circ} \mathrm{C}$ for 7 days, prior to enumeration of viable colonies.

Substrate utilization profiles. The capability of soil microbial communities to utilize a variety of sole carbon sources was assessed using BIOLOG GN2 plates (Biolog Inc., Hayward, CA) by a procedure adapted from Garland and Mills (20) as previously described by Larkin (33). One GN2 plate was prepared for each of two soil subsamples (10 $\mathrm{g}$ of soil serially diluted as described for microbial plate counts), with $150-\mu l$ aliquots of a final dilution of 1:5000 added to each of the 96 wells per plate. The plates were incubated at $22^{\circ} \mathrm{C}$ and optical density was determined on a plate reader at 590 and $760 \mathrm{~nm}$ after 72 and $96 \mathrm{~h}$ of incubation. Optical density readings were corrected for the control (blank) wells on each plate before data analyses. Average well color development (AWCD), calculated as the average optical density across all wells per plate, was used as an indicator of general microbial activity (33). In addition, substrate utilization (SU) data were also analyzed for substrate richness (the number of substrates utilized) and substrate diversity (using Shannon's diversity index) (71).

Fatty acid methyl-ester profiles. Soil community fatty acid profiles were constructed from whole-soil extractions of fatty acid methyl-esters (FAME) according to a modification of the Microbial Identification System (MIS; MIDI, Inc., Newark, DE) standard protocol as described by Larkin (33). Extractions were conducted on each of three 4-g soil subsamples per plot. Each sample was saponified, mixed, heated, methylated, mixed, cooled, extracted, and washed as previously described (33). The organic phase was then transferred to a vial for subsequent analysis by gas chromatography by an automated procedure developed by MIDI, Inc. using an HP 6890 gas chromatograph (Hewlett-Packard, Wilmington, DE) with an HP Ultra-2 capillary column and flame ionization detector. The fatty acids were identified according to the Eukary method and naming table software developed for the MIS. The fatty acid nomenclature used is as follows: total number of carbon atoms: number of double bonds, followed by the position of the double bond from the methyl end of the molecule. Cis and trans geometry are indicated by the suffixes $\mathrm{c}$ and $\mathrm{t}$. Anteiso- and iso-branching are indicated by the suffixes ant and iso. Fatty acids were also analyzed by structural classes, including saturated straight chain, monounsaturated, polyunsaturated, branched, and hydroxy fatty acid classes. These classes and select individual fatty acids were used as indicators (biomarkers) for particular microorganism groups $(3,8,72)$.

Statistical analyses. Soilborne disease, yield, microbial population counts, and most other data were analyzed using standard analysis of variance (ANOVA) with factorial treatment structure and interactions appropriate for a split-block design. FAME data were analyzed by principal components analysis using the covariance matrix followed by multivariate ANOVA (21) and by canonical variates analysis, which serves to maximize differences among treatment groups (8). SU data were analyzed by analysis of covariance and adjusted least square means compared among systems for substrate richness and diversity analyses. AWCD was used as a covariate to account for the influence of AWCD on SU patterns (33). Data from each crop year were analyzed separately; then, data from multiple seasons were also combined and analyzed (with year as an additional factor, with interactons) together to evaluate cumulative and multiyear effects of the cropping systems. Significance was evaluated at $P<0.05$ for all tests. Mean separation was accomplished with Fisher's protected least significant difference test. All analyses were conducted using the Statistical Analysis Systems (ver. 9.1; SAS Institute, Cary, NC). Most microbial assays consisted of three subsamples and five replications (blocks). All SU data presented are based on 72-h incubation readings. 


\section{RESULTS}

Environmental conditions. Weather conditions for the three growing seasons (2006 to 2008) were fairly typical for the area, with 2006 somewhat wetter than normal (particularly from May to July), 2007 somewhat drier than normal, and 2008 close to average rainfall (Table 2). Based on the rainfall amounts and soil moisture trigger, irrigation of $1.3 \mathrm{~cm}$ was applied to all irrigated plots three times (July to August) in 2006, seven times (June to August) in 2007, and four times (July to September) in 2008. Average air temperatures were fairly consistent from year to year and similar to long-term average conditions for the area (Table 2). Other environmental conditions, such as solar radiation and average soil temperature, were also consistent with average conditions for the area (data not shown).

Cropping system and irrigation effects on soilborne diseases. The primary potato diseases observed in each of the three potato seasons assessed were Rhizoctonia stem and stolon canker on the potato plants and black scurf and common scab on the tubers. Rhizoctonia diseases generally occurred at low to moderate severity levels ( 0.3 to $1.5 \%$ surface coverage) and common scab occurred at relatively high severity levels (3.0 to $9.0 \%$ surface coverage) throughout the course of this study. Other potential diseases, such as Verticillium wilt, silver scurf, and powdery scab, were not observed at any time during the study or were only observed quite infrequently and at very low levels. Overall, all cropping systems reduced Rhizoctonia stem and stolon canker relative to continuous potato (PP), with individual yearly reductions of 10 to $50 \%$ and overall average reductions (all years together) of 20 to $30 \%$. However, there were no significant differences among these cropping systems in any year or when averaged over all 3 years (Fig. 1). Irrigation had no significant effect on stem and stolon canker (data not shown).

Black scurf severity levels and cropping system effects varied somewhat from year to year (Table 3). In 2006, scurf levels were low and all cropping systems reduced black scurf relative to PP, with lowest disease levels observed with SI and DS systems under irrigation. In 2007, all rotations except SI reduced scurf, with reductions of 35 to $72 \%$; and, in 2008, only DS reduced scurf severity relative to $\mathrm{PP}$ under both irrigated and nonirrigated conditions, and also reduced scurf relative to all other systems (16 to $35 \%$ reduction). Irrigation tended to result in higher scurf severity (except in 2006) in most cropping systems, averaging $\approx 25 \%$ higher disease severity over all cropping systems in 2007 and 2008 (Table 3). When data for all years were combined, DS averaged significantly lower scurf severity than all other cropping systems under both irrigated and nonirrigated conditions (with reductions of 27 to $58 \%$ ), and irrigated plots averaged $18 \%$ higher scurf severity than nonirrigated plots (Fig. 2A). Incidence of black scurf (percentage of tubers showing symptoms) also differed among cropping systems, with all cropping systems reducing scurf incidence relative to continuous potato, and DS averaging significantly lower scurf incidence than all other cropping systems $(P<0.001$, incidence averaged 67.9, 53.7, 49.4, 48.2, and $38.0 \%$ for PP, SI, SQ, SC, and DS, respectively, over all three seasons).
Cropping system effects on common scab also varied somewhat from year to year but overall consistent results were observed (Table 3 ). In all 3 years, irrigation resulted in higher scab levels than no irrigation, with increases of 10 to $50 \%$. SQ and SC systems reduced scab in some years but only DS reduced scab in all years under both irrigated and nonirrigated conditions, with reductions relative to other rotations of 13 to $42 \%$ (Table 3). SI did not reduce scab in any year. Averaged over all 3 years, DS reduced scab severity better than all other cropping systems ( 25 to $40 \%$ ) and irrigation tended to increase scab levels in each cropping system, averaging a $21 \%$ increase over all systems (Fig. 2B).

Cropping system and irrigation effects on potato yield. In all years, under nonirrigated conditions, both total and marketable yield tended to be highest in the SI system, with yield increases of up to 40 to $60 \%$ higher than other cropping systems. DS also increased both total and marketable yield in all years relative to $\mathrm{PP}$, with increases of 13 to $35 \%$. With irrigation, tuber yields for all systems (except SI) increased by 20 to $40 \%$, generally bringing them comparable with yield levels of SI without irrigation. Under irrigated conditions, DS produced the highest numerical yields, averaging slightly higher (but not significantly different) than SI in all years, and all cropping systems yielded better than PP (by 11 to $24 \%$ ). Similar yield results and effects were observed in each of the three field seasons and were adequately represented by combined data for all 3 years (Fig. 3). Averaged over all 3 years, SI increased yield by $27 \%$ under rainfed conditions, and irrigation increased total yield by 18 to $27 \%$ in different cropping systems and $18 \%$ over all cropping systems (Fig. 3). Total yield from the irrigated DS system averaged 52\% higher than in

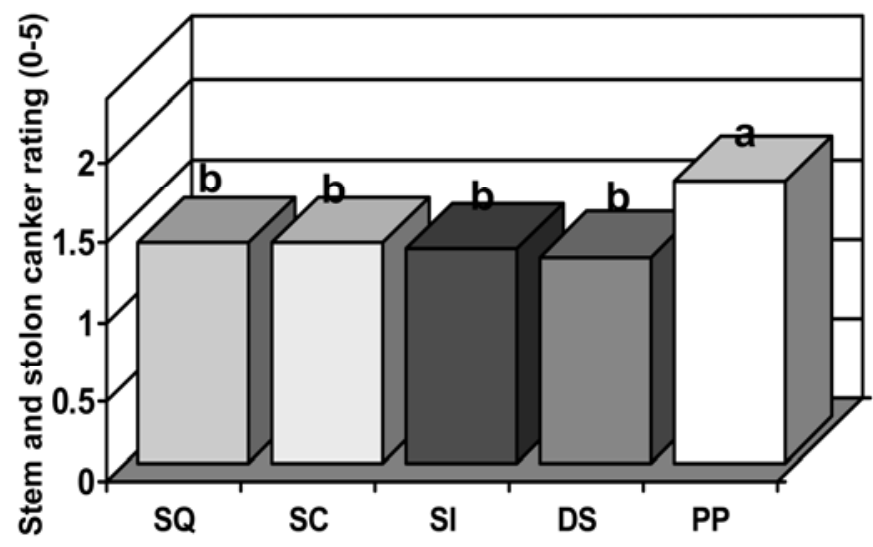

Fig. 1. Effect of cropping system on average severity of stem and stolon canker of potato crop (combined data from three field seasons, 2006-2008). $\mathrm{SQ}=$ status quo system, standard 2-year rotation, (barley/clover-potato); $\mathrm{SC}=$ soil-conserving system, 3-year, limited tillage (barley/timothy-timothy-potato); SI = soil-improving system, 3-year, rotation same as SC but with yearly compost amendments; DS = disease-suppressive system, 3-year, (mustard blend GM/rapeseed cover crop-sudangrass GM/rye cover crop-potato); $\mathrm{PP}=$ continuous potato, nonrotation control. Bars topped by the same letter are not significantly different from each other based on analysis of variance and Fisher's protected least significant difference test $(P=0.05)$.

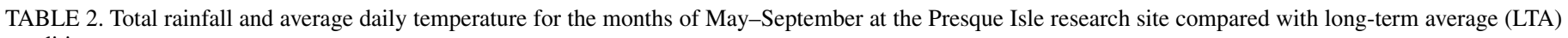
conditions

\begin{tabular}{|c|c|c|c|c|c|c|c|c|}
\hline \multirow[b]{2}{*}{ Month } & \multicolumn{4}{|c|}{ Rainfall $(\mathrm{cm})$} & \multicolumn{4}{|c|}{ Average daily air temperature $\left({ }^{\circ} \mathrm{C}\right)$} \\
\hline & 2006 & 2007 & 2008 & LTA & 2006 & 2007 & 2008 & LTA \\
\hline May & 11.3 & 6.1 & 5.3 & 8.7 & 12.7 & 10.7 & 10.1 & 11.4 \\
\hline June & 10.9 & 5.1 & 11.6 & 8.6 & 18.1 & 16.7 & 15.9 & 16.4 \\
\hline July & 11.7 & 9.8 & 8.2 & 9.4 & 20.3 & 19.0 & 20.4 & 19.0 \\
\hline August & 6.3 & 12.0 & 11.2 & 10.0 & 16.1 & 17.3 & 17.7 & 18.2 \\
\hline September & 7.1 & 4.3 & 7.9 & 8.7 & 13.1 & 14.1 & 13.7 & 13.2 \\
\hline Total & 47.3 & 37.3 & 44.2 & 45.4 & 80.3 & 77.8 & 77.8 & 78.4 \\
\hline
\end{tabular}


nonirrigated PP. Full details and year-by-year analyses of total and marketable tuber yield and relationships with soil and plant properties and characteristics will be provided in a subsequent article.

Cropping system and irrigation effects on soil microbial community characteristics. Soil microbial community data from soil samples collected from all plots in the spring of each year prior to planting potato indicated consistent and highly significant effects due to cropping system for most parameters in all years, whereas irrigation had little effect on soil microbial characteristics at this time of sampling. Combined data averaged over all 3 crop years best illustrated the observed effects. Soil samples demonstrated consistent differences in soil moisture among cropping systems, with SI soil averaging higher soil moisture than all other systems, and DS and PP soils averaging lower soil moisture (Table 4).

Overall average populations of culturable bacteria and fungi were higher in SI soils than all other cropping systems, with bacterial populations in DS soils next highest, and lowest microbial populations observed in PP soils (Table 4). General microbial activity, as estimated by average SU across numerous carbon sources (AWCD), indicated highest activity in the SI and SQ soils and lowest activity in the PP soils. Substrate diversity was higher in DS soil than all other systems and lowest in PP soil, and substrate richness (number of substrates effectively utilized) was slightly higher in DS (but comparable with SC and SQ) soil and lowest in PP soil (Table 4).

Analysis of the soil fatty acid data indicated that soil FAME profiles were distinctly different for each of the cropping systems, and that overall characteristics for each system were fairly consistent from year to year. Graphical depiction of the first two canonical variates (CV1 and CV2) from canonical variates analysis from combined data for all 3 years illustrated that soil from each cropping system had microbial characteristics that were very distinct from each other system (Fig. 4). Irrigation also had some effects on soil microbial characteristics but these effects were minor compared with cropping system effects, as indicated by the greater separation among the cropping systems and closer proximity of the irrigated and not irrigated values for each cropping system. Interestingly, the SI and DS systems showed the greatest effects on soil microbiology (evident by the greater separation from the SQ and PP systems) but each showed very different effects (SI showing lower values for CV1 and DS lower values for CV2). Analysis of FAME structural classes and individual fatty acids of importance in differentiating the cropping system FAME profiles revealed corresponding differences among the cropping system soils for all the structural classes, indicator ratios, and microbial indicator FAMEs (Table 5). SI soil generally had a relatively low proportion of straight-chain saturated fatty acids, high levels of monounsaturated FAMEs, and moderate-low levels of polyunsaturated FAMEs. SC had the highest relative polyunsaturated, high monounsaturated, and lowest saturated levels of FAMEs. DS had relatively high saturated, low monounsaturated, and high polyunsaturated FAME levels, and PP had the highest relative saturated and lowest mono- and polyunsaturated fatty acids of all cropping systems (Table 5). These differences resulted in correspondingly distinct differences in the ratio of monounsaturated to saturated fatty acids among cropping systems, with SC having the highest ratio and PP the lowest. Other differences of note among the cropping systems included variations in the levels of indicator FAMEs for actinomycetes, mycorrhizae, and fungi; and ratios of gram-positive to gramnegative bacteria and fungal to bacterial FAMEs (Table 5). Overall, DS soil had the highest proportion of 18:2 $\omega 6 \mathrm{c}$, a biomarker for fungi, among cropping systems, as well as a high proportion of biomarkers for actinomycetes, and a high ratio of gram-positive to gram-negative FAMEs. SI soil had the highest proportion of the mycorrhizae biomarker FAME (16:1 $\omega 5 \mathrm{c}$ ) among cropping systems, whereas DS and PP had the lowest level of the mycorrhizae biomarker. PP soil also had the lowest levels of the fungi marker and the fungi/bacteria ratio. All these differences indicate that each cropping system affected microbial communities in distinct and different ways.

\section{DISCUSSION}

In this research, combined results from three potato seasons following full rotation cycles with cropping systems specifically designed to address management issues of soil conservation, soil improvement, and disease suppression demonstrated that cropping system significantly affected soilborne disease, soil microbial communities, and potato yield. In related studies, these cropping systems also significantly affected various other soil physical, chemical, and biological properties.

Each of the designated cropping systems apparently did accomplish their respective management goals. SI, through addition of organic matter as composted dairy manure, had the greatest effects on soil properties and improved soil quality through numerous measured parameters, including increasing soil organic matter, active $\mathrm{C}$, and particulate organic matter $\mathrm{C}$ and $\mathrm{N}$; increasing water holding capacity, the percentage of water stable aggregates; decreasing soil resistance to penetration; and de-


2008) $)^{\mathrm{Z}}$

\begin{tabular}{|c|c|c|c|c|c|c|}
\hline \multirow[b]{3}{*}{ Disease, system } & \multicolumn{6}{|c|}{ Disease severity (percent surface coverage) } \\
\hline & \multicolumn{2}{|c|}{2006} & \multicolumn{2}{|c|}{2007} & \multicolumn{2}{|c|}{2008} \\
\hline & Nonirrigated & Irrigated & Nonirrigated & Irrigated & Nonirrigated & Irrigated \\
\hline \multicolumn{7}{|l|}{ Black scurf } \\
\hline Status quo & $0.35 \mathrm{c}$ & $0.47 \mathrm{~b}$ & $0.45 \mathrm{~b}$ & $0.41 \mathrm{c}$ & $0.87 \mathrm{a}$ & $1.27 \mathrm{a}$ \\
\hline Soil-conserving & $0.47 \mathrm{~b}$ & $0.35 \mathrm{bc}$ & $0.40 \mathrm{~b}$ & $0.84 \mathrm{~b}$ & $0.88 \mathrm{a}$ & $0.99 \mathrm{~b}$ \\
\hline Soil-improving & $0.30 \mathrm{c}$ & $0.23 \mathrm{c}$ & $1.00 \mathrm{a}$ & $1.29 \mathrm{a}$ & $0.91 \mathrm{a}$ & $1.07 \mathrm{~b}$ \\
\hline Disease-suppressive & $0.45 \mathrm{~b}$ & $0.29 \mathrm{c}$ & $0.28 \mathrm{~b}$ & $0.39 \mathrm{c}$ & $0.62 \mathrm{~b}$ & $0.85 \mathrm{c}$ \\
\hline Continuous potato & $0.62 \mathrm{a}$ & $0.67 \mathrm{a}$ & $0.94 \mathrm{a}$ & $0.88 \mathrm{~b}$ & $0.93 \mathrm{a}$ & $1.07 \mathrm{~b}$ \\
\hline $\operatorname{LSD}(P=0.05)$ & 0.09 & 0.13 & 0.17 & 0.28 & 0.13 & 0.12 \\
\hline \multicolumn{7}{|l|}{ Common scab } \\
\hline Status quo & $5.45 \mathrm{ab}$ & $7.51 \mathrm{~b}$ & $6.41 \mathrm{~b}$ & $6.58 \mathrm{c}$ & $6.24 \mathrm{a}$ & $6.83 \mathrm{ab}$ \\
\hline Soil-conserving & $4.84 \mathrm{~b}$ & $6.07 \mathrm{c}$ & $6.77 \mathrm{ab}$ & $8.12 \mathrm{~b}$ & $5.15 \mathrm{~b}$ & $5.73 \mathrm{c}$ \\
\hline Soil-improving & $6.23 \mathrm{a}$ & $9.40 \mathrm{a}$ & $7.88 \mathrm{a}$ & $9.16 \mathrm{a}$ & $5.86 \mathrm{ab}$ & $6.61 \mathrm{~b}$ \\
\hline Disease-suppressive & $5.21 \mathrm{~b}$ & $5.56 \mathrm{c}$ & $6.33 \mathrm{~b}$ & $6.16 \mathrm{c}$ & $3.99 \mathrm{c}$ & $5.91 \mathrm{bc}$ \\
\hline Continuous potato & $6.21 \mathrm{a}$ & $9.13 \mathrm{a}$ & $7.73 \mathrm{a}$ & $9.04 \mathrm{ab}$ & $6.39 \mathrm{a}$ & $7.28 \mathrm{a}$ \\
\hline $\operatorname{LSD}(P=0.05)$ & 0.96 & 1.22 & 1.20 & 0.94 & 0.95 & 0.74 \\
\hline
\end{tabular}

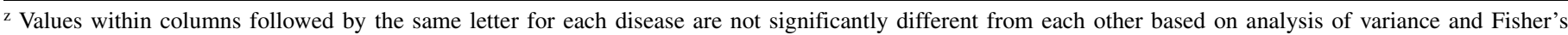
protected least significant difference (LSD) test $(P<0.05)$. 
creasing bulk density (Larkin et al., unpublished). SI also affected plant growth characteristics, such as increasing leaf area index and duration relative to all other systems (Larkin et al., unpublished). SC improved soil conservation (relative to the standard, 2-year, SQ rotation) by limiting tillage, reducing erosion, and lengthening the rotation period. However, in this study, these changes in the SC system did not result in significant effects on soil properties, diseases, yield, or most soil microbial assessments relative to the SQ rotation. Thus, the soil conservation approach by itself did not produce results much different from the SQ rotation, at least in the short-term assays done here. Several other studies have also observed that these types of changes (limited tillage or additional year of rotation) often do not result in significant changes within the first few years of implementation $(9,10,23)$. However, after multiple years, these approaches would be expected to show benefits compared with the 2-year rotation,
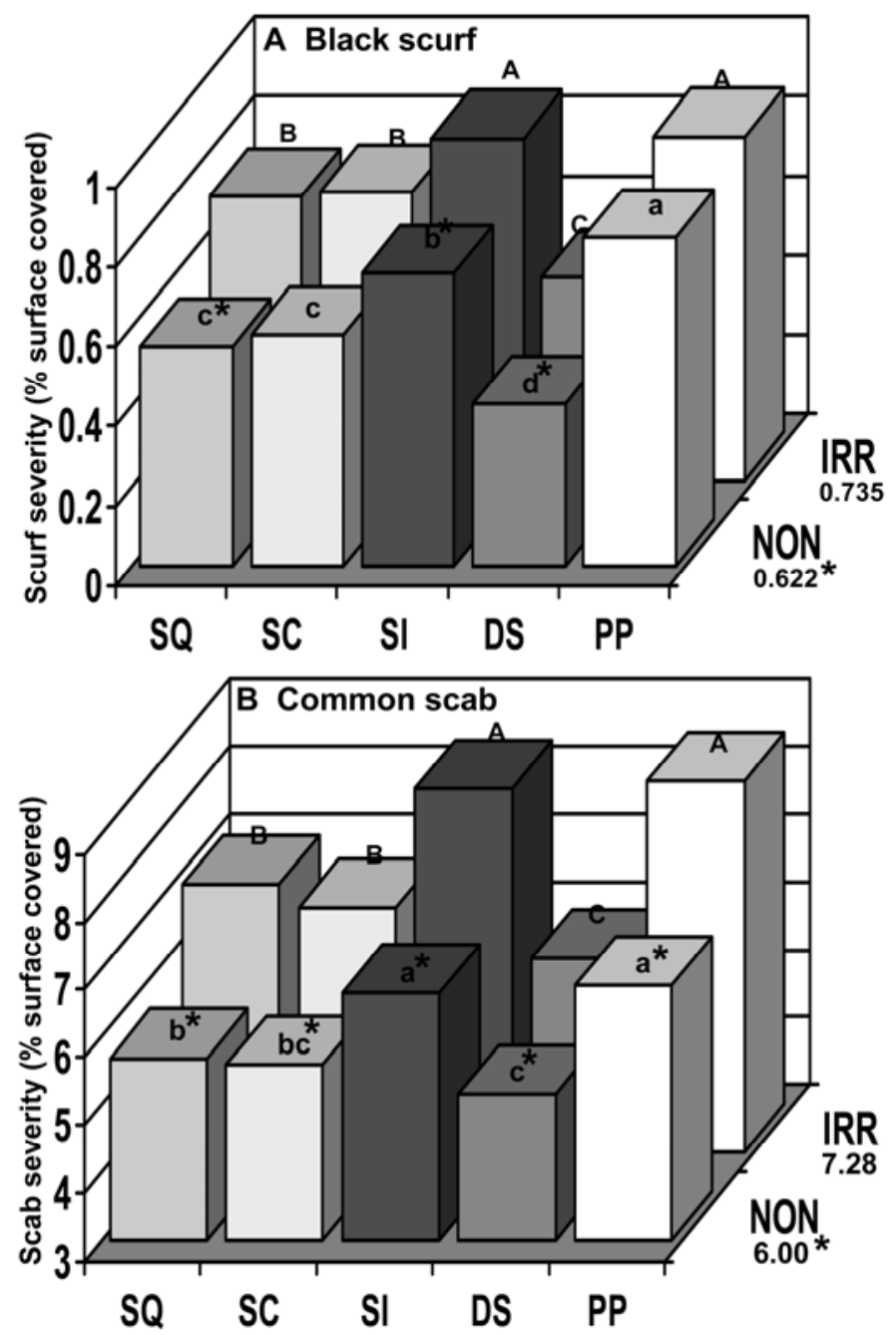

Fig. 2. Effect of different cropping systems with and without irrigation on severity of tuber diseases A, black scurf (caused by Rhizoctonia solani) and $\mathbf{B}$, common scab (caused by Streptomyces scabiei) (combined data from three field seasons, 2006-2008). SQ = status quo system, standard 2-year rotation, (barley/clover-potato); SC = soil-conserving system, 3-year., limited tillage (barley/timothy-timothy-potato); SI = soil-improving system, 3-year, rotation same as SC but with yearly compost amendments; DS = disease-suppressive system, 3-year, (mustard blend GM/rapeseed cover crop-sudangrass GM/ rye cover crop-potato); $\mathrm{PP}=$ continuous potato, nonrotation control; IRR= Irrigated; NON = nonirrigated. Bars within each irrigation regime topped by the same letter are not significantly different from each other based on analysis of variance and Fisher's protected least significant difference test $(P<$ $0.05)$. Bars topped by an asterisk represent values that are significantly lower than their corresponding value for that cropping system in the other irrigation regime $(P<0.05)$. particularly regarding soilborne diseases, as has been shown in numerous studies comparing 2-year versus 3-year rotations and tillage effects $(10,57,58)$. The SC system was significantly different from the SQ system for many of the soil FAME characteristics, including FAME classes and ratios and biomarkers, indicating that there were microbial community differences as a result of the SC approaches. Nelson et al. (51) also observed that soil physical and chemical properties were not affected in the first few years of transition to a longer-term organic potato rotation at multiple sites but that soil microbial characteristics were significantly affected. Soil microbial communities are often the quickest and most responsive to changes in cropping and management practices $(19,53,67,70)$, and these changes may be the beginning of future effects of the SC system on other crop and soil properties.

Although all rotations reduced soilborne diseases to some degree (compared with no rotation), the DS system, consisting of Brassica and sudangrass green manure crops, fall cover crops, and high crop diversity, resulted in the greatest reductions in stem and stolon canker, black scurf, and common scab relative to the other rotations, under both irrigated and nonirrigated conditions, thus accomplishing the disease-suppressive objective. DS also produced significant shifts in soil microbial community characteristics different from all other rotations. Thus, the strategies used for the disease suppression system (the use of diseasesuppressive biofumigation rotation crops, cover crops, and crop diversity) successfully reduced disease relative to other rotations. Although disease severity levels were fairly low throughout the study for black scurf, the reductions observed due to DS were still highly significant. Previous studies with rotation crops similar to those in the DS rotation also demonstrated that comparable reductions in black scurf incidence and severity also occurred in soils where black scurf levels were much higher (35-37). Thus, similar reductions in disease would be expected even with higher than observed levels of black scurf.

Biofumigation refers to the breakdown of plant metabolites in soil to produce volatile compounds that can reduce populations of weeds, nematodes, and plant pathogens. Crops in the Brassi-

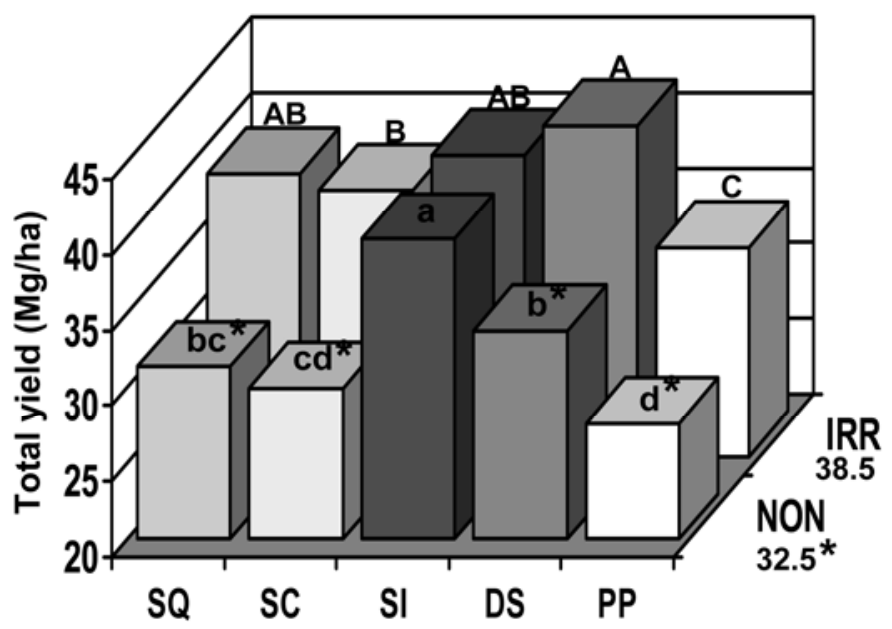

Fig. 3. Effect of different cropping systems with and without irrigation on total tuber yield (combined data from three field seasons, 2006-2008). SQ = status quo system, standard 2-year rotation, (barley/clover-potato); SC = soilconserving system, 3-year., limited tillage (barley/timothy-timothy-potato); $\mathrm{SI}=$ soil-improving system, 3-year, rotation same as SC but with yearly compost amendments; DS = disease-suppressive system, 3-year, (mustard blend $\mathrm{GM} /$ rapeseed cover crop-sudangrass GM/ rye cover crop-potato); $\mathrm{PP}=$ continuous potato, nonrotation control; IRR = Irrigated; NON = nonirrigated. Bars within each irrigation regime topped by the same letter are not significantly different from each other based on analysis of variance and Fisher's protected least significant difference test $(P<0.05)$. Bars topped by an asterisk represent values that are significantly lower than their corresponding value for that cropping system in the other irrigation regime $(P<0.05)$. 
caceae family produce glucosinolates that break down to produce isothiocyanates, whereas sudangrass produces cyanogenic glucosides that break down to produce hydrogen cyanide, that are toxic to many soil organisms $(45,60)$. Use of these plants as rotation, cover, or green manure crops has been shown to reduce pathogens or diseases $(6,31,50,54,62)$, nematodes $(7,49)$, and weeds $(4,5)$, and to improve soil characteristics and crop yield (47). Although biofumigation is the presumed mechanism of action for these crops, further research has indicated that additional mechanisms, including specific changes in soil microbial communities not related to levels of glucosinolate or other toxic metabolites, are also important in the reduction of soilborne diseases by Brassica crops, particularly for the control of Rhizoctonia spp. (11,14, $15,35,46)$. At the very least, effects on soil microbial communities also play an important role in these interactions. In recent trials, incorporation of mustard residues (B. juncea) consistently resulted in greater effects on soil microbial communities and greater reductions in soilborne diseases than additions of other organic amendments, or when mustard was not incorporated (18). In recent studies in potato systems, incorporation of either rye or mustard residues increased root health and also increased yield relative to fallow and ryegrass; however, mustard was superior to rye, and incorporation of whole mustard plants was superior to either roots or shoots alone (63).

The use of cover crops and increasing overall crop diversity has also been associated with modest but significant reductions in soilborne diseases $(17,36,64)$. The mechanism for these interactions primarily involves increasing soil microbial populations and microbial diversity. Cover crops with large, numerous, and penetrating root systems provide richer microbial habitats. In recent research on the Great Plains, alternative cropping systems characterized by more diverse crop sequences, greater cropping intensity, or reduced tillage resulted in greater microbial biomass, improved soil properties, and overall enhanced soil function that was attributed to improved retention and cycling of nutrients and maintenance of biodiversity and habitat (39). Different types of plants and root systems stimulate and provide nutrition for more varied microorganisms, presumably leading to greater antagonism and inhibition of pathogens $(19,53,67,70)$. In this research, effects on soil microbial communities were distinctly different for DS than all other systems, with higher levels of substrate diversity and richness, indicators of microbial diversity, and unique changes in FAME biomarkers compared with the other cropping

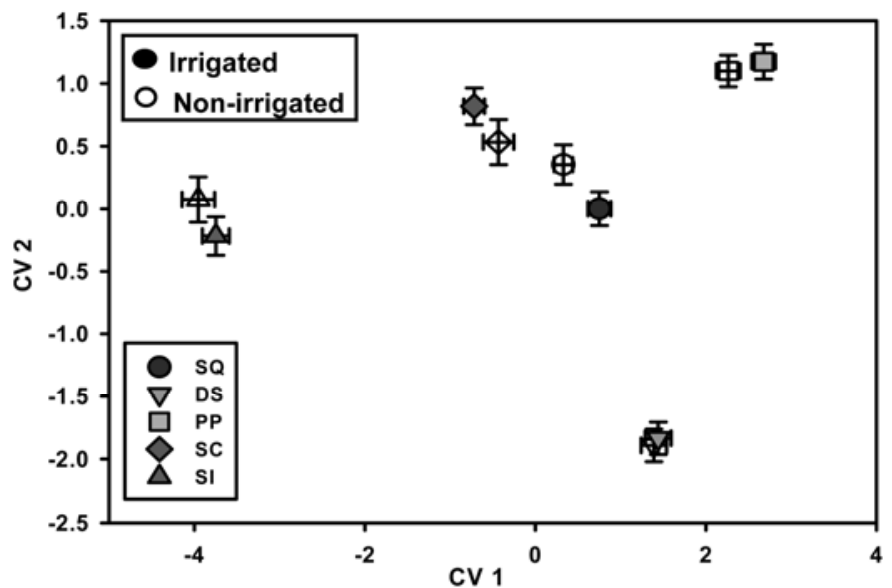

Fig. 4. Effect of different cropping systems with and without irrigation on soil microbial community characteristics, as represented by canonical variates (CVs) 1 and 2 from CV analysis of soil fatty acid methyl-ester profiles (combined data from three field seasons, 2006-2008). SQ = status quo system, standard 2-year rotation, (barley/clover-potato); $\mathrm{SC}=$ soil-conserving system, 3-year, limited tillage (barley/timothy-timothy-potato); SI = soil-improving system, 3-year, rotation same as SC but with yearly compost amendments; DS = disease-suppressive system, 3-year, (mustard blend GM/rapeseed cover crop-sudangrass GM/ rye cover crop-potato); $\mathrm{PP}=$ continuous potato, nonrotation control; filled shapes $=$ irrigated; open shapes $=$ nonirrigated.

TABLE 4. Effect of different cropping systems on selected soil microbial parameters averaged over three field seasons (2006-2008)

\begin{tabular}{|c|c|c|c|c|c|c|}
\hline \multirow[b]{2}{*}{ System $^{\mathrm{y}}$} & \multicolumn{3}{|c|}{ Microbial populations } & \multicolumn{3}{|c|}{ Substrate utilization } \\
\hline & Soil moisture $(\%)$ & Bacteria $\left(\times 10^{7} / \mathrm{g}\right.$ of soil $)$ & Fungi $\left(\times 10^{4} / \mathrm{g}\right)$ & Activity ${ }^{\mathrm{Z}}$ & Richness & Diversity \\
\hline SQ & $25.1 \mathrm{c}$ & $4.39 \mathrm{c}$ & $47.9 \mathrm{~b}$ & $0.682 \mathrm{a}$ & $51.2 \mathrm{ab}$ & $4.02 \mathrm{~b}$ \\
\hline $\mathrm{SC}$ & $28.0 \mathrm{~b}$ & $4.30 \mathrm{c}$ & $39.3 \mathrm{~b}$ & $0.608 \mathrm{c}$ & $51.3 \mathrm{ab}$ & $4.03 \mathrm{~b}$ \\
\hline SI & $33.0 \mathrm{a}$ & $5.77 \mathrm{a}$ & $52.9 \mathrm{a}$ & $0.675 \mathrm{a}$ & $50.0 \mathrm{~b}$ & $4.01 \mathrm{~b}$ \\
\hline DS & $23.9 \mathrm{~d}$ & $4.81 \mathrm{~b}$ & $46.9 \mathrm{~b}$ & $0.628 \mathrm{~b}$ & $51.4 \mathrm{a}$ & $4.05 \mathrm{a}$ \\
\hline PP & $23.3 \mathrm{~d}$ & $3.04 \mathrm{~d}$ & $42.2 \mathrm{c}$ & $0.522 \mathrm{~d}$ & $47.7 \mathrm{c}$ & $3.93 \mathrm{c}$ \\
\hline
\end{tabular}

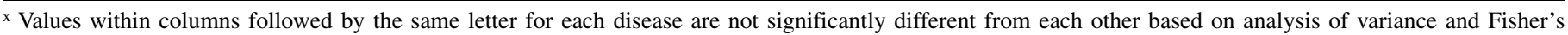
protected least significant difference (LSD) test $(P<0.05)$.

y $\mathrm{SQ}=$ status quo, $\mathrm{SC}=$ soil-conserving, $\mathrm{SI}=$ soil-improving, $\mathrm{DS}=$ disease-suppressive, and $\mathrm{PP}=$ continuous potato systems.

${ }^{\mathrm{z}}$ Average well color development.

TABLE 5. Effect of different cropping systems on relative proportions of fatty acid methyl-ester (FAME) classes and indicator ratios and fatty acids as averaged over three field seasons $(2006-2008)^{\mathrm{s}}$

\begin{tabular}{|c|c|c|c|c|c|c|c|c|c|}
\hline \multirow[b]{2}{*}{ System $^{t}$} & \multicolumn{4}{|c|}{ FAME classes $(\%)^{\mathrm{u}}$} & \multicolumn{5}{|c|}{ FAME ratios and biomarkers } \\
\hline & Satur. & Mono. & Poly. & Mono./Satur. & $\mathrm{G}+/ \mathrm{G}-\mathrm{v}$ & Fung./bact. ${ }^{w}$ & Actinomy. ${ }^{\mathrm{x}}$ & Mycorr. ${ }^{\mathrm{y}}$ & Fung. ${ }^{2}$ \\
\hline SQ & $30.8 \mathrm{c}$ & $26.4 \mathrm{~b}$ & $7.9 \mathrm{bc}$ & $0.87 \mathrm{c}$ & $1.41 \mathrm{c}$ & $0.172 \mathrm{~b}$ & $1.92 \mathrm{ab}$ & $5.32 \mathrm{c}$ & $4.59 \mathrm{~b}$ \\
\hline SC & $27.6 \mathrm{e}$ & $29.8 \mathrm{a}$ & $11.5 \mathrm{a}$ & $1.10 \mathrm{a}$ & $1.48 \mathrm{ab}$ & $0.198 \mathrm{a}$ & $1.52 \mathrm{~b}$ & $5.98 \mathrm{~b}$ & $4.62 \mathrm{~b}$ \\
\hline DS & $31.6 \mathrm{~b}$ & $24.3 \mathrm{c}$ & $8.2 \mathrm{~b}$ & $0.78 \mathrm{~d}$ & $1.49 \mathrm{a}$ & $0.183 \mathrm{~b}$ & $1.97 \mathrm{a}$ & $2.77 \mathrm{~d}$ & $5.08 \mathrm{a}$ \\
\hline PP & $33.8 \mathrm{a}$ & $21.5 \mathrm{~d}$ & $6.3 \mathrm{~d}$ & $0.65 \mathrm{e}$ & $1.43 \mathrm{bc}$ & $0.114 \mathrm{~d}$ & $1.76 \mathrm{~b}$ & $2.73 \mathrm{~d}$ & $3.32 \mathrm{~d}$ \\
\hline
\end{tabular}

s Values within columns followed by the same letter for each disease are not significantly different from each other based on analysis of variance and Fisher's protected least significant difference (LSD) test $(P<0.05)$.

t $\mathrm{SQ}=$ status quo, $\mathrm{SC}=$ soil-conserving, $\mathrm{SI}=$ soil-improving, $\mathrm{DS}=$ disease-suppressive, and $\mathrm{PP}=$ continuous potato systems.

" Satur. = saturated, Mono. = monounsaturated, Poly. = polyunsaturated, and Mono./Satur. = ratio of monounsaturated to saturated.

${ }^{v}$ Ratio of gram-positive to gram-negative.

${ }^{\mathrm{w}}$ Ratio of fungi to bacteria.

${ }^{x}$ Actinomycetes (10 methyl).

${ }^{y}$ Mycorrhizae (16:1 $\left.\omega 5 \mathrm{c}\right)$.

${ }^{\mathrm{z}}$ Fungi $(18: 2 \omega 6 \mathrm{c})$. 
systems. Some of these changes in soil microbial characteristics may be related to the disease suppression observed (37).

Although it cannot be determined which aspects of the DS system were most effective in these trials, the integration of these multiple strategies did accomplish the goal of reducing disease. This disease-suppression strategy also resulted in high yields throughout the study, producing the highest numerical yields (comparable with SI) under irrigated conditions, and higher than all systems but SI under nonirrigated conditions. However, although this DS system resulted in generally favorable results regarding reduced soilborne diseases and increased yield, this rotation was devised for experimental purposes only and would not be a viable rotation for potato production, due to the lack of economic return in two of the three rotation years. However, a form of this DS rotation, incorporating the DS principles into a single rotation year followed by a more conventional, profitable crop in the third year, may have potential for improved sustainable potato production.

The SI system was the same rotation as SC, just with the addition of yearly compost amendments. Yet, the addition of compost had dramatic effects on many parameters. As mentioned previously, SI had the greatest effects on soil properties and also tended to increase soil moisture, tuber yield, and microbial populations and activity, and resulted in substantial shifts in soil microbial community characteristics. However, SI also resulted in relatively high levels of black scurf and common scab (comparable with PP). Although compost amendments are generally associated with reductions in soilborne diseases, results can be quite variable and depend on many factors (52). Recently, Termorshuizen et al. (68) evaluated a wide range of composts against a range of pathogens and diseases with a consortium of researchers from several countries and, of the 120 bioassays using 18 composts and seven pathosystems, just over half (54\%) resulted in significant disease suppression, while $43 \%$ showed no effect and only $3 \%$ resulted in increased disease. The most important factors appear to be the compost materials, age, maturity, and quality (27). As with cover crops, the mechanism of action is most closely associated with stimulation of microbial populations and microbial diversity, although induction of induced systemic resistance has also been documented with some composts (73). Perez-Piqueres et al. (56) reported that changes in the microbial community structure induced by compost amendments were related to both the soil and the type of organic amendment applied, and that differences in disease suppression were related to differences in chemical composition and microbial composition due to both stimulation of indigenous organisms and incorporation of microorganisms derived from the compost amendments. On the other hand, Saison et al. (59) concluded that the effects of compost amendments on soil microbial communities were mostly due to the physicochemical characteristics of the compost rather than the introduction of compost-borne microorganisms.

Although it has been commonly reported and accepted that additions of animal manure tend to increase scab problems, there appears to be little empirical evidence to directly support this assertion (13). Previous reports of increased scab associated with manure appear to be primarily related to increased $\mathrm{pH}$ effects (which is known to increase scab) or to scab inoculum contained within the manure (from feeding livestock diseased cull potato tubers) rather than to any direct effects of the manure itself (13). Several recent studies have indicated that common scab can be substantially reduced with certain manure amendments but that effects are very dependent on the specific properties of the manures and soils involved $(13,48)$. Although the compost used in the present study was derived from dairy manure, amendments did not increase soil $\mathrm{pH}$ or contain pathogen inoculum. Thus, the presence of manure in these amendments was not likely directly related to the relatively high disease levels observed compared with other cropping systems. It also should be noted that, although some disease levels were higher with SI than some of the other rotations, SI did not result in increases of any disease at any time (relative to continuous potato). SI was just not effective in reducing disease levels compared with the other rotations.

Overall, SI contributed generally favorable results but did not result in reduction of soilborne diseases. Increased microbial activity, in this case, was not associated with lower disease levels. Although the relatively high disease levels observed with SI were not associated with adverse yield effects in this study, the potential for future disease problems would be a concern in the long term. Perhaps by working with the type, age, and maturity of the compost used, the positive yield results could be supplemented with disease suppression as well. Many of the effects of the compost amendments observed here may be related to increased water-holding capacity. SI tended to have the highest soil moisture and effectively substituted for irrigation in most years, retaining adequate moisture levels to achieve adequate yields even when moisture was limiting in other rotations. The increased water-holding capacity provided by compost amendments was apparently able to compensate for low soil water availability.

Irrigation improved yield substantially in most cropping systems (all but SI) in all years, even in 2006, which was wetter than normal and during which irrigation was only applied a total of three times. Apparently, even small applications of water during the crucial August tuber-bulking period can lead to substantial differences in yield. However, irrigation also tended to increase disease problems for both black scurf and common scab. With respect to common scab, this finding is contrary to many previous reports and traditional conventional wisdom that irrigation, and particularly irrigation during the 6 weeks following tuber initiation, tends to reduce common scab problems $(16,32)$. However, more recent reports and anecdotal grower observations have noted inconsistent results and, sometimes, high scab levels even when following irrigation guidelines (25) (E. Banks, personal communication). In our research in Maine soils and environmental conditions, we have fairly consistently observed at least comparable if not greater scab in irrigated versus nonirrigated plots (unpublished data). Whether these results are due to changes within the pathogen itself, specific environmental conditions, or other attributes cannot be determined from this study. However, it appears that the relationship between soil moisture and scab is more complex than previously thought.

Irrigation did not have any major effects on soil microbial community characteristics, which were much more closely related to cropping systems. In the absence of irrigation, SI produced significantly higher yield than all other rotations. Thus, increased soil water, whether through irrigation or compost amendments, was related to higher yields but also relatively high soilborne disease. Overall disease levels were not closely related to yield, with DS having low disease but high yields, and irrigated and SI systems having high disease and high yields.

FAME profiles revealed distinct differences in soil microbial community characteristics associated with each rotation. Differences in FAME profiles were related to differences within both the bacterial and fungal communities, with differences generally associated with bacterial communities primarily delineated along CV1 and those of fungi along CV2. The DS and SI systems each resulted in microbial community characteristics that were very different from PP or SQ systems yet were also quite different from each other, indicating that they affected communities in very different ways. DS resulted in a higher level of the FAME biomarkers for actinomycetes and fungi compared with all other cropping systems. FAME 16:1 $155 \mathrm{c}$ was important for differentiating among cropping systems, with SI showing the highest levels, indicating higher mycorrhizae populations, and DS and PP showing the lowest levels. Thus, although mycorrhizae may have 
been associated with some disease reduction in SC and SQ systems relative to PP, high levels in SI did not result in disease reduction, and disease reduction within DS was not associated with mycorrhizae. Microbial community differences between PP and DS were apparently more closely related to differences in fungal characteristics. Thus, the specific ways that the DS system affected microbial communities was quite distinct from those of the other cropping system, and was presumably related to the Brassica crops within that rotation system. Brassica crops have been observed to have effects on soil microbial communities that are different from most other crops or other additions of organic matter (18). In other potato research, fungal diversity was greater and species composition differed in longer rotations than in continuous, or short-term rotations, and nonrotations resulted in increased pathogen densities (44). The distinctive cropping system effects on soil microbial community characteristics represented by FAME profiles observed here for the DS system are consistent with those observed in our previous rotation studies with Brassica crops $(33,34,36,37)$, and indicate that these effects on soil microbial communities due to cropping systems are distinct, consistent, and repeatable. Further work is continuing to identify more specific effects on microbial composition and their roles in disease suppression.

Overall, soil water, soil quality, and soilborne diseases were all important factors involved in constraining productivity, and systems addressing these constraints enhanced productivity. However, for future long-term productivity, it will likely be necessary to balance the need for low disease levels with sustainable cropping practices to optimize yields. Thus, a cropping system incorporating the DS system approaches (disease-suppressive rotations, cover crops, and crop diversity), with irrigation and some of the SC or SI system soil-quality inputs (limited tillage and organic amendments) and a profitable third-year crop, may provide potential for enhanced sustainable production and disease management.

\section{ACKNOWLEDGMENTS}

We thank the many people who have worked on or contributed to this research in various ways over the years of these studies, from summer workers and student aides, field crews, technicians, colleagues, and miscellaneous hands and expertise; L. Matthiesen for her thorough and capable technical assistance on all aspects of this work; D. Cowperthwaite for managing and maintaining the field site; P. Pinette, G. Trusty, E. Mallory, E. Champaco, B. LeGasse, and D. Torrey for additional technical support; and all the others without whom these largescale, long-term studies could never be completed.

\section{LITERATURE CITED}

1. Abdallahi, M. M., and N'Dayegamiye, A. 2000. Effects of green manures on soil physical and biological properties and on wheat yields and $\mathrm{N}$ uptake. Can. J. Soil Sci. 80:81-89.

2. Ball, B. C., Bingham, I., Rees, R. M., and Watson, C. A. 2005. The role of crop rotations in determining soil structure and crop growth conditions. Can. J. Plant Sci. 85:557-577.

3. Bossio, D. A., and Scow, K. M. 1998. Impacts of carbon and flooding on soil microbial communities: phospholipid fatty acid profiles and substrate utilization patterns. Microb. Ecol. 35:265.

4. Boydston, R. A., and Hang, H. A. 1995. Rapeseed (Brassica napus) green manure crop suppresses weeds in potato (Solanum tuberosum). Weed Technol. 9:669-675.

5. Brown, P. D., and Morra, M. J. 1995. Glucosinolate-containing plant tissues as bioherbicides. J. Agric. Food Chem. 43:3070-3074.

6. Brown, P. D., and Morra, M. J. 1997. Control of soilborne plant pests using glucosinolate-containing plants. Adv. Agron. 61:167-231.

7. Buskov, S., Serra, B., Rosa, E., Sorense, H., and Sorensen, J. C. 2002. Effects of intact glucosinolates and products produced from glucosinolates in myrosinase-catalyzed hydrolysis on the potato cyst nematode (Globodera rostichiensis). J. Agric. Food Chem. 50:690-695.

8. Buyer, J. S., Roberts, D. P., and Russeck-Cohen, E. 1999. Microbial community structure and function in the spermosphere as affected by soil and seed type. Can. J. Microbiol. 45:138-144.

9. Carter, M. R., Holmstrom, D., Sanderson, J. B., Ivany, J. A., and DeHaan, R. 2005. Comparison of conservation with conventional tillage for potato production in Atlantic Canada: crop productivity, soil physical properties and weed control. Can. J. Soil Sci. 85:453-461.

10. Carter, M. R., and Sanderson, J. B. 2001. Influence of conservation tillage and rotation length on potato productivity, tuber disease and soil quality parameters on a fine sandy loam in eastern Canada. Soil Till. Res. 63:113 .

11. Cohen, M. F., Mazzola, M., and Yamasaki, H. 2005. Brassica napus seed meal soil amendment modifies microbial community structure, nitric oxide production and incidence of Rhizoctonia root rot. Soil Biol. Biochem. 37:1215-1227.

12. Collins, H. P., Alva, A. K., Boydston, R. A., Cochran, R. L., Hamm, P. B., McGuire, A., and Riga, E. 2006. Soil microbial, fungal, and nematode responses to soil fumigation and cover crops under potato production. Biol. Fertil. Soils 42:247-257.

13. Conn, K. L., and Lazarovits, G. 1999. Impact of animal manures on Verticillium wilt, potato scab, and soil microbial populations. Can. J. Plant Pathol. 21:81-92.

14. Davis, J. R., Huisman, O. C., Westermann, D. T., Everson, D. O., Schneider, A., and Sorensen, L. H. 2004. Some unique benefits with sudangrass for improved U.S.\#1 yields and size of Russet Burbank potato. Am. J. Potato Res. 81:403-413.

15. Davis, J. R., Huisman, O. C., Westermann, D. T., Hafez, S. L., Everson, D. O., Sorensen, L. H., and Schneider, A. T. 1996. Effects of green manures on Verticillium wilt of potato. Phytopathology 86:444-453.

16. Davis, J. R., McMaster, G. M., Callihan, R. H., Nissley, F. H., and Pavek, J. J. 1976. Influence of soil moisture and fungicide treatments on common scab and mineral content of potatoes. Phytopathology 66:228-233.

17. Fageria, N. K., Baligar, V. C., and Bailey, B. A. 2005. Role of cover crops in improving soil and row crop productivity. Commun. Soil Sci. Plant 36:2733-2757.

18. Friberg, H., Edel-Hermann, V., Faivre, C., Gautheron, N., Fayolle, L., Faloya, V., Montfort, F., and Steinberg, C. 2009. Cause and duration of mustard incorporation effects on soil-borne plant pathogenic fungi. Soil Biol. Biochem. 41:2075-2084

19. Garbeva, P., van Veen, J. A., and van Elsas, J. D. 2004. Microbial diversity in soil: selection of microbial populations by plant and soil type and implications for disease suppressiveness. Annu. Rev. Phytopathol. 42:243270.

20. Garland, J. L., and Mills, A. L. 1991. Classification and characterization of heterotrophic microbial communities on the basis of patterns of community-level sole-carbon-source utilization Appl. Environ. Microbiol. 57:2351-2359.

21. Glimm, E., Heuer, H., Engelen, B., Smalla, K., and Backhaus, H. 1997. Statistical comparisons of community catabolic profiles. J. Microbiol. Methods 30:71-80.

22. Grandy, A. S., Porter, G. A., and Erich, M. S. 2002. Organic amendment and rotation crop effects on the recovery of soil organic matter and aggregation in potato cropping systems. Soil Sci. Soc. Am. J. 66:13111319.

23. Griffin, T. S., Larkin, R. P., and Honeycutt, C. W. 2009. Delayed tillage and cover crop effects in potato systems. Am. J. Potato Res. 86:79-87.

24. Halloran, J. M., Griffin, T. S., and Honeycutt, C. W. 2005. An economic analysis of potential rotation crops for Maine potato cropping systems. Am. J. Potato Res. 82:155-162.

25. Haynes, K. G., Wanner, L. A., Thill, C. A., Bradeen, J. M., Miller, J., Novy, R. G., Whitworth, J. L., and Corsini, D. L. 2010. Common scab trials of potato varieties and advanced selections at three U.S. locations. Am. J. Potato Res. 87:261-276.

26. Hoekstra, O. 1989. Results of twenty-four years of crop rotation research at 'De Schreef' experimental site. In: Effects of Crop Rotation on Potato Production in the Temperate Zones. J. Vos, C. D. van Loon, and G. J. Bollen, eds. Kluwer Academic Publishers, Dordrecht, The Netherlands.

27. Hoitink, H. A. J., Stone, A. G., and Han, D. Y. 1997. Suppression of plant diseases by compost. HortScience 32:184-187.

28. Honeycutt, C. W., Clapham, W. M., and Leach, S. S. 1996. Crop rotation and $\mathrm{N}$ fertilization effects on growth, yield, and disease incidence in potato. Am. Potato J. 73:45-61.

29. Karlen, D. L., Eash, N. S., and Unger, P. W. 1992. Soil and crop management effects on soil quality indicators. Am. J. Altern. Agric. 7: 48-55.

30. Karlen, D. L., Hurley, E. G., Andrews, S. S., Cambardella, C. A., Meek, D. W., Duffy, M. D., and Mallarino, A. P. 2006. Crop rotation effects on soil quality at three northern corn/soybean belt locations. Agron. J. 98:484-495.

31. Kirkegaard, J. A., Wong, P. T. W., and Desmarchelier, J. M. 1996. In vitro suppression of fungal root pathogens of cereals by Brassica tissues. Plant Pathol. 45:593-603. 
32. Lapwood, D. H., Wellings, L. W., and Hawkins, J. H. 1973. Irrigation as a practical means to control potato common scab (Streptomyces scabies): Final experiment and conclusions. Plant Pathol. 22:35-41.

33. Larkin, R. P. 2003. Characterization of soil microbial communities under different potato cropping systems by microbial population dynamics, substrate utilization, and fatty acid profiles. Soil Biol. Biochem. 35:14511466.

34. Larkin, R. P. 2008. Relative effects of biological amendments and crop rotations on soil microbial communities and soilborne diseases of potato. Soil Biol. Biochem. 40:1341-1351.

35. Larkin, R. P., and Griffin, T. S. 2007. Control of soilborne diseases of potato using Brassica green manures. Crop Prot. 26:1067-1077.

36. Larkin, R. P., Griffin, T. S., and Honeycutt, C. W. 2010. Rotation and cover crop effects on soilborne potato diseases, tuber yield, and soil microbial communities. Plant Dis. 94:1491-1502.

37. Larkin, R. P., and Honeycutt, C. W. 2006. Effects of different 3-year cropping systems on soil microbial communities and Rhizoctonia diseases of potato. Phytopathology 96:68-79.

38. Larkin, R. P., Hopkins, D. L., and Martin, F. N. 1993. Ecology of Fusarium oxysporum f. sp. niveum in soils suppressive and conducive to Fusarium wilt of watermelon. Phytopathology 83:1105-1116.

39. Leibig, M., Carpenter-Boggs, L., Johnson, J. M. F., Wright, S., and Barbour, N. 2006. Cropping system effects on soil biological characteristics in the Great Plains. Renew. Agric. Food Syst. 21:36-48.

40. Little, S. A., Hocking, P. J., and Greene, R. S. B. 2004. A preliminary study of the role of cover crops in improving soil fertility and yield for potato production. Commun. Soil Sci. Plant 35:471-494.

41. MacRae, R. J., and Mehuys, G. R. 1985. The effect of green manuring on the physical properties of temperate-area soils. Adv. Soil Sci. 3:71-94.

42. Magdoff, F. 2000. Concepts, components, and strategies of soil health in agroecosystems. J. Nematol. 33:169-172.

43. Magdoff, F., and van Es, H. 2000. Cover crops and crop rotations. In: Building Soils for Better Crops. Sustainable Agriculture Publications, University of Vermont, Burlington.

44. Manici, L. M., and Caputo, F. 2009. Fungal community diversity and soil health in intensive potato cropping systems of the east Po valley, northern Italy. Ann. Appl. Biol. 155:245-258.

45. Matthiessen, J. N., and Kirkegaard, J. A. 2006. Biofumigation and enhanced biodegradation: opportunity and challenge in soilborne pest and disease management. Crit. Rev. Plant Sci. 25:235-265.

46. Mazzola, M., Granatstein, D. M., Elfving, D. C., and Mullinix, K. 2001. Suppression of specific apple root pathogens by Brassica napus seed meal amendment regardless of glucosinolate content. Phytopathology 91:673679.

47. McGuire, A. N. 2003. Mustard green manures replace fumigant and improve infiltration in potato cropping system. Crop Manage. Online. doi: 10.1094/CM-2003-0822-01-RS

48. Mishra, K. K., and Srivastana, J. S. 2004. Soil amendments to control common scab of potatoes. Potato Res. 47:101-109.

49. Mohjtahedi, H., Santo, G.S., and Wilson, J. H. 1993. Managing Meloidogyne chitwoodii on potato with rapeseed as green manure. Plant Dis. 77:42-46.

50. Muelchen, A. M., Rand, R. A., and Parke, J. L. 1990. Evaluation of crucifer green manures for controlling Aphanomyces root rot of peas. Plant Dis. 74:651-654.

51. Nelson, K. L., Lynch, D. H., and Boiteau, G. 2009. Assessment of changes in soil health throughout organic potato rotation sequences. Agric. Ecosyst. Environ. 131:220-228.

52. Noble, R., and Coventry, E. 2005. Suppression of soil-borne plant diseases with composts: A review. Biocontrol Sci. Technol. 15:3-20.

53. O’Donnell, A. G., Seasman, M., MacRae, A., Waite, I., and Davies, J. T. 2001. Plants and fertilisers as drivers of change in microbial community structure and function in soils. Plant Soil 232:135-145.

54. Olivier, C., Vaughn, S. F., Mizubuti, E. G., and Loria, R. 1999. Variation in allyl isothiocyanate production within Brassica species and correlation with fungicidal activity. J. Chem. Ecol. 25:2687-2701.

55. Pankhurst, C. E., Doube, B. M., and Gupta, V. V. S. R. 1997. Biological Indicators of Soil Health. CAB International, Oxon, UK.

56. Perez-Piqueres, A., Edel-Hermann, V., Alabouvette, V., and Steinberg, C. 2006. Response of soil microbial communities to compost amendments. Soil Biol. Biochem. 38:460-470.

57. Peters, R. D., Sturz, A. V., Carter, M. R., and Sanderson, J. B. 2003. Developing disease-suppressive soils through crop rotation and tillage management practices. Soil Till. Res. 72:181-192.

58. Peters, R. D., Sturz, A. V., Carter, M. R., and Sanderson, J. B. 2004. Influence of crop rotation and conservation tillage practices on the severity of soil-borne potato diseases in temperate humid agriculture. Can. J. Soil Sci. 84:397-402.

59. Saison, C., Degrange, V., Oliver, R., Millard, P., Commeaux, C., Montange, D., and Le Roux, X. 2006. Alteration and resilience of the soil microbial community following compost amendment: Effects of compost level and compost-borne microbial community. Environ. Microbiol. $8: 247-257$

60. Sarwar, M., Kirkegaard, J. A., Wong, P. T. W., and Desmarchelier, J. M. 1998. Biofumigation potential of Brassicas. III. In vitro toxicity of isothiocyanates to soil-borne fungal pathogens. Plant Soil 210: 103-112.

61. Scholte, K. 1987. The effect of crop rotation and granular nematicides on the incidence of Rhizoctonia solani in potato. Potato Res. 30:187-199.

62. Smolinska, U., and Horbowicz, M. 1999. Fungicidal activity of volatiles from selected cruciferous plants against resting propagules of soil-borne fungal pathogens. J. Phytopathol. 147:119-124.

63. Snapp, S. S., Date, K. U., Kirk, W., O’Neill, K., Kremen, A., and Bird, G. 2007. Root, shoot tissues of Brassica juncea and Cereal secale promote potato health. Plant Soil 294:55-72.

64. Snapp, S. S., Swinton, S. M., Labarta, R., Mutch, D., Black, J. R., Leep, R., Nyiraneza, J., and O'Neil, K. 2005. Evaluating cover crops for benefits, costs, and performance within cropping system niches. Agron. J. 97:322-332.

65. Specht, L. P., and Leach, S. S. 1987. Effects of crop rotation on Rhizoctonia disease of white potato. Plant Dis. 71:433-437.

66. Stark, C., Condron, L. M., Stweart, A., Di, H. J., and O'Callaghan, M. 2007. Influence of organic and mineral amendments on microbial soil properties and properties. Appl. Soil Ecol. 35:79-93.

67. Sturz, A. V., and Christie, B. R. 2003. Beneficial microbial allelopathies in the root zone: the management of soil quality and plant disease with rhizobacteria. Soil Till. Res. 72:107-123.

68. Termorshuizen, A. J., van Rijn, E., van der Gaag, D. J., Alabouvette, C., Chen, Y., Lagerlof, J., Malandrakis, A. A., Paplomatas, E. J., Ramert, B., Ryckeboer, J., Steinberg, C., and Zmora-Nahum, S. 2006. Suppressiveness of 18 composts against 7 pathosystems: variability in pathogen response. Soil Biol. Biochem. 38:2461-2477.

69. Thorup-Kristensen, K., Magid, J., and Jensen, L. S. 2003. Catch crops and green manures as biological tools in nitrogen management in temperate zones. Adv. Agron. 79:227-302.

70. Van Elsas, J. D., Garbeva, P., and Salles, J. 2002. Effects of agronomical measures on the microbial diversity of soils as related to the suppression of soil-borne plant pathogens. Biodegradation 13:29-40.

71. Zak, J. C., Willig, M. R., Moorhead, D. L., and Wildman, H. G. 1994. Functional diversity of microbial communities: A quantitative approach. Soil Biol. Biochem. 26:1101-1108.

72. Zelles, L., Bai, Q. Y., Beck, T., and Beese, F. 1992. Signature fatty acids in phospholipids and lipposaccharides as indicators of microbial biomass and community structure in agricultural soils. Soil Biol. Biochem. 24:317-323.

73. Zhang, W., Han, D. Y., Dick, W. R., Davis, K. R., and Hoitink, H. A. J. 1998. Compost and water extract-induced systemic acquired resistance in cucumber and Arabidopsis. Phytopathology 88:450-455. 